\title{
"Hedged in by Ecclesiastical and Racial Contrivances": United Church Missions in Western Canada, 1925-1940
}

\section{Michael Owen}

Volume 56, 1989

Changements culturels et éducation de la foi

Cultural Change and Education of the Faith

URI : https://id.erudit.org/iderudit/1006954ar

DOI : https://doi.org/10.7202/1006954ar

Aller au sommaire du numéro

Éditeur(s)

Les Éditions Historia Ecclesiæ Catholicæ Canadensis Inc.

ISSN

0318-6172 (imprimé)

1927-7067 (numérique)

Découvrir la revue

Citer cet article

Owen, M. (1989). "Hedged in by Ecclesiastical and Racial Contrivances": United Church Missions in Western Canada, 1925-1940. Sessions d'étude - Société canadienne d'histoire de l'Église catholique, 56, 35-61.

https://doi.org/10.7202/1006954ar

Tous droits réservés @ Les Éditions Historia Ecclesiæ Catholicæ Canadensis Inc., 1989
Ce document est protégé par la loi sur le droit d'auteur. L'utilisation des services d'Érudit (y compris la reproduction) est assujettie à sa politique d'utilisation que vous pouvez consulter en ligne. 


\title{
"Hedged in by Ecclesiastical and Racial Contrivances": United Church Missions in Western Canada, 1925-1940
}

\author{
Michael OwEN \\ Athabasca University
}

The missionary endeavours of Protestant denominations in Western Canada are not well understood by social historians. Home missionaries are viewed narrowly as agents of the dominant Anglo-Protestant society bent upon converting powerless and reluctant foreign immigrants to the twin gospels of Canadianism and Protestant Christianityl. The home missionaries - doctors, nurses, teachers, deaconesses, and evangelists become narrow bigoted men and women intent on stamping out the individuality and culture of New Canadians. New Canadians are depicted as faceless hordes settled on the urban, agricultural or mining frontiers.

This narrow view of home missionaries and their clients does disservice to both. For the clients, by no means a homogenous mass of European or Asian immigrants, a view that depicts them as powerless and acted upon fails to recognize the powerful forces operating within ethnic communities; the way in which these communities used the services of the churches for their own purposes; or the way in which individuals parlayed linguistic skills and political influence within the ethnic community into

1 See John Higham, Strangers in the Land: Patterns of American nativism 1860-1925 (New York: Atheneum, 1978), pp. 237-238, 6-9; John Higham, Send These To Me: Immigrants in Urban America (Baltimore: Johns Hopkins University Press, 1984), pp. 43-47; and Howard Palmer, Patterns of Racism: A History of Nativism in Alberta (Toronto: McClelland and Stewart, 1982), pp. 9-10, 37-45; Marilyn Barber, "Nationalism, Nativism and the Social Gospel," IN The Social Gospel in Canada, ed. Richard Allen (Ottawa: National Museum of Man, 1975), pp. 186-225; John Webster Grant, "The Reaction of WASP Churches to Non-WASP Immigrants", Presidential Address to the Canadian Society of Church History, 1968; John Webster Grant, "Religion and the Quest for a National Identity: The background in Canadian History", IN Religion and Culture in Canada, ed. Peter Slater (Waterloo: CCSR, 1977), pp. 7-21; and N.K. Clifford, "〈His Dominion〉: A Vision in Crisis", in Religion and Culture, pp. 23-41.A In this paper, I subscribe to the paradigm of nativism as described in Higham, Palmer and Barber. 
employment with the churches or government agencies, to the benefit of both the community and the individual. Also ethnic immigrants were not the only focal points for the home mission enterprise in Canada. Coreligionists from Scotland or England, the Maritimes or Ontario, were the first concern of the home mission enterprise.

In this paper, I attempt to map out some of the factors that influenced the development and maintenance of the home mission enterprise of the United Church of Canada in the Canadian West in the period 1925-1940. Specifically, I describe some of the home mission functions of the United Church. These "missions" had a wide variety of characteristics. Some were "extension" missions, that is "missions" to adherents in the suburbs, literally efforts to extend the services of the church to individuals identified with the church but who had relocated to suburbs. Other missions were efforts to extend the services of the church to the agricultural or mining frontiers. These services were efforts to maintain contact with adherents but also to evangelize others who were not members of the church. Finally, there were missions to the ethnic minorities on the prairies. In this case missionaries attempted to evangelize among individuals and communities that had no ties with the United Church (Protestant) tradition or to Christianity.

A number of specific themes assist in this overall task of outlining some social factors that impacted upon the United Church mission enterprise: (1) Church Union and Home Missions, (2) Urban Growth and Rural Depopulation, and (3) Missions and New Canadians. There are, of course, many other themes that could be explored. These three themes, however, dominated the reports on the home missions in the period.

\section{Church Union and Home Missions}

Throughout the first quarter of the twentieth century, the Methodist Presbyterian churches, as well as the Congregational churches, discussed, debated and agonized over a union of the denominations. While the Union movement has been subjected to analyses by participants and historians ${ }^{2}$,

2 For detailed discussions of the union movement, see N.K. Clifford, The Resistance to church union 1904-1939 (Vancouver: UBC Press, 1985); N.K. Clifford, "Church union and western Canada", in D.L. Butcher et al., Prairie Spirit: Perspectives on the heritage of the United Church of Canada in the West (Winnipeg: University of Manitoba Press, 1985, pp. 283-295; N.K. Clifford, "The Interpreters of the United Church of Canada", Church History 46 (June 1977), pp. 203-214; Donald S. Moore, "Presbyterian Non-concurrence and the United Church of Canada", The Bulletin No. 24 (1975), pp. 28-39; Mary Vipond, "Canadian National Consciousness and the Formation of the United Church of Canada", The Bulletin No. 24 (1977), pp. 5-27. 
little attention has been paid to the support for union among home missionaries in western Canada or upon the impact of union on home missions. It is my contention (unproven as yet) that up to 1925, the union movement had little direct impact upon missions to the ethnic minorities, the major mission churches having agreed in 1911 to partition the immigrant minorities in order to promote efficient evangelism and nationalisation and to prevent overlap and competition. Similarly, the Methodist and Presbyterian churches agreed informally and, in 1921, formally to reduce overlap in the rural settlements across the west ${ }^{3}$. These agreements did not prevent acrimonious accusations of encroachment by one denomination against the other, but, on the whole, did enable the denominations to use more efficiently scarce resources allocated to home missions and church extension.

The first report of the United Church Board of Home Missions (1926) was, in essence, two reports - one for the Presbyterian wing and one for the Methodist wing; Congregational missions were not mentioned. The reports highlighted the contributions that each brought to the new Church. The United Church's home mission enterprise was comprehensive: the marine missions in Newfoundland and on the Pacific Coast, missions to the aboriginal peoples of the western provinces, missions to ethnic minorities in from Sydney to Toronto and Port Arthur, Winnipeg, Vegreville, and Victoria; and missions to Anglo-Protestant settlements in the western provinces and on the mining, agricultural and industrial frontiers.

The Presbyterian section underlined the support for Union from the home mission interests of the uniting churches:

The United Church of Canada is a national Church... It was in national necessity that the vision of this new Church was born. Because the divided Churches were not able to meet the demands of the situation in Canada, men conceived the idea of a United Church. It was the vision of a Church, expressing our Canadian life and ministering to our Canadian needs that was the inspiration of many a dark hour in the years just past. And now the new Church is here - a great fact in the life of the nation... This new Church is of Canada, unifying as well as united....

It follows, therefore, that there is nothing truer to the genius of this new Church than Home Missions... The purpose of Home Missions is to carry the Gospel into all parts of the country especially into those places where not yet could it plant and support itself, and where there lie special problems and perils to be met. It is helping to create and fertilize the soil out of which healthy and safe national life can grow ${ }^{4}$.

3 See "Minutes of Joint Committee of the Methodist and Presbyterian Churches in Alberta on Co-operation", 1911, 1913, 1914, 1917, 1918, 1921. Public Archives of Alberta, United Church of Canada Collection.

4 United Church of Canada, The United Church of Canada Yearbook, 1926, p. 330. (Hereafter cited as Yearbook). 
The Methodist report, "Our Responsibility", asserted that

No more important responsibility confronts the Church, nor any more patriotic duty, than to use to the utmost her resources in men and money in providing the teachings of Christianity to those peoples who have settled in areas where sparseness of population or poverty or some other disability makes it impossible for the work to be self-supporting. Human need, often tragic, is found in such regions and if by our indifference or irresolution these... are deprived of the solace and strength of the Gospel, surely we shall be held accountable...5

The 1927 renort of the Board of Home Missions revealed the centrality of the mission experience to congregants of the United Church: 1518 charges, missions and institutions, serving 4105 preaching stations, or "almost 48 per cent of the worshipping units of the whole church". Of these the Western Provinces had 2,3396. To J.H. Edmison and C.E. Manning, joint secretaries of the Board of Home Missions, if the spectre of national spiritual illiteracy was to be overcome it was essential to maintain the home mission infrastructure of hospitals, school homes and boarding schools for school-age children in remote centres, community missions, aboriginal missions, extended fields, and "non-Anglo-Saxon" missions.

One victim (and cause) of "spiritual illiteracy" was the stranger both the immigrants from Eastern Europe, the British Isles and the United States, and those from settled regions who migrated to the frontier (rural, industrial or urban frontier). Though powerful pre-war xenophobic reactions to the stranger had subsided, the Home Mission Board and its agents continued to fear the religious, moral and political impact of continental European immigration on the national life of Canada. Whereas in the pre and immediate post-war era, it was not unusual to read in the published records of the Methodist and Presbyterian churches views of the "foreigner" that were racist, by the 1930s United Church missionaires and bureaucrats spoke more often of "New Canadians" and their actual and potential contributions to the Canadian nation?. This, in my view, was more than a shift in terminology and represented a shift in attitude to the New Canadian - a positive shift. While some continued to denigrate the impact of the New Canadian on rural life on the pairies and in the cities, others argued that the United Church and the Canadian nation had come to accept the New Canadians as they were and assisted their integration into Canadian society, not necessarily a complete assimilation to Canadian Protestant norms.

5 Ibid., p. 320.

6 Ibid., 1927, p. 109.

7 See Michael Owen, "Building the Kingdom of God on the Prairies: E.H. Oliver and Saskatchewan Education, 1913-1930, "Saskatchew'an History XL: 1 (Winter 1987). pp. 21-32. 
If the expressions of concern about the foreigner were more circumscribed as immigration and natural increase swelled the numbers of non-Anglo-Saxon Canadians, United Church mission superintendents noted two encouraging trends. The first was the number of "Protestant people from Continental Europe", an estimated 49,000 between 1924 and 1927 , a number greater than Protestant adherents who had arrived from the United Kingdom in the same period. Many of the Continental Europeans claimed "the spiritual guidance of the United Church8." The second cause was the vastly reduced numbers of immigrants. In 1928, for example, immigration to Canada had numbered only 166,782 , a far cry from the nearly 500,000 that arrived in 1913-14. Hence, the United Church believed that with some effort, it would be possible to meet the spiritual needs of most of these new immigrants and to accommodate them within Canadian life. These tasks were made more manageable by the large numbers of immigrants, both British and continental Europeans, who utilized the services of the church's chaplains at ports-of-entry. In 1928, for example, the United Church reported that 39,832 of these immigrants, including 15,098 from the United Kingdom, had made contact with its officials. "The 24,734 Non-Anglo-Saxons reported to us included over twenty different nationalities9." If in some quarters complaints against the "increasing number" of continental immigrants were heard, 10 these were overshadowed by the expressed need to minister to British, American and Canadian migrants to the frontier. Church rolls rarely increased as rapidly as did the population or even that portion of the population that claimed adherence to the United Church.

\section{Urban Growth and Rural Depletion}

The United Church saw itself, in spite of its increasingly urban concentration, as a rural church. However, by 1929 the Home Mission Board

8 Ihid., pp. 112-3. It is interesting to note that both the Presbyterian and United churches claimed to have been instrumental in the development of Protestantism in post-war Eastern Europe. Indeed, both churches claimed the same worker, the Rev. Paul Crath. See Presbyterian Church in Canada. General Assembly, Acts and Proceedings, 1933, p. 50; Yearbook, 1927, p. 114. For additional information on the status of Protestantism in the Ukraine in the inter-war period, see Ian F. Mackinnon, Canada and the Minority Churches of Eastern Europe, 1946-1950 (Halifax: The Book Room, 1954), pp. 110-116.

9 Yearbook, 1929, p. 123.

10 An interesting footnote to these statistics is the report of Rev. Wm Farquharson, D.D., who stated: "summing up the returns for ten years previous to 1927-28, the number of British exceeds that from all other countries, exluding the United States, by over one hundred thousand. ... [S]ome Western correspondents - while maintaining that British Settlers at their best are unexcelled - are strongly inclined to prefer the hardy settlers from Northern Europe who come unaided to push their own way, to the class of British who need assisted passages, and too often look for further help whenever fresh difficulty arises." Ibid, p. 124. 
had reported that "the most needy communities religiously" were not "in our old-time countryside, but in the heart of our rapidly growing cities." The Canadian frontier had shifted to the city. It became the "main work" of the church, once again, "to make good cities - clean and God-fearing cities... He who makes the city makes the nation." 11 The neverending growth of urban centres, demanding greater attention from home mission superintendents and greater funds from the limited fiscal resources, increased the fear of church leaders on the impact that cities had on the church. This anxiety about urban issues had four interrelated causes: nonAnglo-Celtic settlements within the cities, decline of inner city districts, the growth of suburban communities, and the depletion of the AngloProtestant rural population. These concerns were not new, the rhetoric of the reports of home mission superintendents in the late 1920s mirroring the reports of the Methodist and Presbyterian social reformers in the 1910s.

In the 1920s and 1930s, the United Church was forced to reconsider its emphasis on the rural ministry and traditional modes of evangelism and social service. It was not without irony that the Board of Home Missions compared the "pioneering" of earlier missionaries with the task that confronted clergy in the 1930's:

[F]ew missionaries of the United Church are still pioneering..., but far too many of them are compelled to work to-day in a decadent countryside, whose rapidly diminishing population robs them of vigorous youth, and whose local prejudices make progress almost impossible. Some of them pioneer among the polyglot population of our modern cities, throwing their lives against the sin and selfishness, sickness and poverty, bootlegging and graft of these modern Gothams. For many of these workers, the splendor of the sunset on the trail is to-day shut out by skyscrapers, and the roar of machinery drowns the voice of God ${ }^{12}$.

The rapidly shifting frontier compelled the Board of Home Mission to reconsider the image of the United Church as a "Rural Church". Urban "racial, economic and social frontiers" begged for attention ${ }^{13}$. Gradually concerns expressed by urban missionaries for two decades were understood by members of the Home Mission Board:

If the Church fails in these growing cosmopolitan centres, there is no hope for the country. The daily newspaper, telephone, radio, moving picture and motor roads

11 Yearbook, 1929, p. 120. See Michael Owen, "Keeping Canada God's Country": Presbyterian Perspectives on Selected Social Issues, 1900-1915" (Unpublished Ph.D. dissertation, University of Toronto, 1984), Chapter IV; Paul Rutherford, "Tomorrow's metropolis: The urban reform movement in Canada, 1880-1920," in Gilbert A. Stetler and Alan F.J. Artibise, eds., The Canadian city: Essays in urban history (Toronto: McClelland and Stewart, 1977), pp. 368-382.

12 Yearbook, 1936, pp. 104-105.

13 Yearbook, 1939, p. 77. 
are all helping to urbanize the rural mind. Unfortunately it is not always the best things in city life that are being copied in the country ${ }^{14}$.

The decline of the inner city district and the expansion of the suburbs garnered the attention of mission superintendents. In Winnipeg, Vancouver and Edmonton missionaries recommended action to counter the malevolent influences of the deterioration of inner city districts and to bolster the influence of the church in the social and political life of the city. To J.A. Cormie, home mission superintendent for Manitoba, "the deteriorating area" of Winnipeg spread "as the older families move to the suburbs". The issue was: "How to make the church an effective force among those who are left behind and to care for those in the growing suburbs..." These were two sides of the same problem ${ }^{15}$. Ministers and the church struggled to keep in touch with communicants migrating to the suburbs as well as inmigrants from the rural communities and Europe. The establishment of suburban congregations placed heavy demands upon the church funds for the purchase or land and building new churches. Winnipeg's suburbs, and those in other western municipalities, were not always affluent districts established by middle class individuals fleeing life in the centre city but also the home to recent migrants from the depleted rural communities and British and European immigrants 16 .

Throughout the 1930s, suburban churches were considered to be one of the weakest sectors in the United Church. In Winnipeg, suburban congregations had "been weakened in morale and financial strength by the long continued unemployment, and with two exceptions, their buildings are inadequate and not creditable to a Church like ours ${ }^{17}$." Moreover, in suburban districts, ministers served as spiritual and morale builders, and relief agents for congregants and communities, distributing relief goods supplied by churches in Eastern Canada.

Although the Church found it impossible to meet the needs of the recent migrants to new suburban communities, it was in the city centre that the Church confronted the real urban problem. By the 1920s, most Canadian cities had developed a "slum" district (or at the very least tenements, substandard housing, and overcrowded apartments and houses, often the residences of recent immigrants from central and eastern Europe), usually near the central business district. The United Church, as with other Protestant churches, feared the impact of slums and overcrowding on the moral and social life of the community and reacted conservatively to meet the spiritual, social and material needs of the inner city

14 Yearbook, 1932, p. 135.

15 Yearbook, 1930, p.

16 Yearbook, 1936, p. 111.

17 Yearbook, 1939, p. 92. 
resident, usually establishing social settlements or evangelical missions. These missions usually focused on the New Canadian. United Church urban missions in western Canadian cities included the All People's Mission and Robertson Memorial Institute in Winnipeg, the Settlement House in Regina, and the All People's Mission, Buchanan Institute and Bissell Mission in Edmonton.

In the years immediately following Union, the main clients of these missions were immigrant women, children and youth ${ }^{18}$.

\begin{abstract}
In some thirty-four centres The United Church of Canada has organized enterprises among the various Non-Anglo-Saxon groups. In the large centres of population these efforts are confined largely to the children and to the young people, although some of the most interesting and surprising results have also been experienced among the older people... The work among the children and young people gathers together into a common fellowship the representatives of many peoples and breaks down racial barriers that have separated these people so widely.... No more patriotic work is done anywhere than this splendid undertaking on behalf of these children. Were the influences of these institutions and missions felt in all Non-Anglo-Saxon communities how very soon would this generation of young people respond to the appeal to follow Him, who is Lord of all nations! 19
\end{abstract}

This pattern of institutional missions serving primarily urban nonAnglo-Celtic clients became more pronounced as the 1930s progressed. By 1938, Winnipeg missions were "all in that section of the city from which the Anglo-Saxons are moving, and they are exercising a good influence in a district in which the Canadian point of view has few interpreters 20 ."

Without undervaluing the evangelical underpinnings of the missions, outreach services provided, first, for the social and material needs of the clients and, second, for the state, a "nationalising" function. As such, these services represented a continuation of the assimilationist and nationbuilding tradition of the Methodist and Presbyterian churches. That is, these United Church missions were actively part of the infrastructure for integrating non-Anglo-Celtic immigrants and their off-spring into the Canadian nation. Unlike the pre-war missions, however, mission staff and home mission superintendents did not discuss the goals of the missions within the ethnocentric and "hard" paradigm of their predecessors. Instead they represented the "softer" view of social reformers, and Canadians in general, toward the European immigrants 21 .

\footnotetext{
18 Yearbook, 1931, pp. 158-9.

19 Yearbook, 1927, p. 114. Emphasis added.

20 Yearbook, 1938, p. 117

21 Owen, “Keeping Canada God's Country”, pp. 46-67.
} 
United Church mission workers fit within the paradigm of "child savers" and urban reformers in the same way as other "secular" social workers and educational reformers 22 . After an expansionist period in the 1920 's, by the early 1930's urban missions reduced paid staff compliments and shifted more of the mission work to unpaid volunteers. These missions, however, attempted to maintain their programs of Tuxis groups, social clubs, sabbath schools, women's organizations, CGIT, and, wherever possible, one or two week excursion (i.e., summer camps) for women and children who frequented mission. The urban missionary served as spiritual advisor, relief agent, educator for citizenship, and, importantly, untrained psychologist and social worker, to provide mental relief from familial problems and those imposed by overcrowded living conditions and long-term unemployment. These nominally non-spiritual roles of the mission workers increased in importance throughout the 1930s In the view of J.A. Cormie "no persons are more closely in touch with the homes of the people or more competent to direct relief [than the staff of the institutional mission]." The urban missions were, therefore, "centres of relief24" whose usefulness, especially within the crowded inner city districts, was evident to both the mission worker and the client.

Mission workers themselves perceived their task within a nationbuilding paradigm, although there was little direct discussion of the role that missions played in "Canadianizing" the New Canadian. A careful reading of the reports of the home mission superintendents reveal that "assimilation" remained a major component of mission work. But assimilation had come to mean more than simple adherence to the mores of the dominant Anglo-Celtic society. Assimilation meant peaceful co-existence between ethnic subgroups as well. For example, Elizabeth Stephen of Winnipeg's Point Douglas Mission candidly explained one of the two underlying goals of her work with the New Canadian children:

It is a rare privilege ours of moulding and shaping the personalities of little children. This has been the aim of our kindergarten and in 1932 we had the largest kindergarten class in the history of Point Douglas.... They have heard about the boys and girls of other lands and filled a 'cent-a-day' card during November, ... as an expression of their love for their little yellow and brown and

22 For theoretical discussions of the work of child-saving in the late nineteenth and early twentieth centuries see, Neil Sutherland, Children in English-Canadian Society: Framing the Twentieth Century Consensus (Toronto: University of Toronto Press, 1976); Andrew Jones and Leonard Rutman, In the Children's Aid: I.I. Kelso and Child Welfare in Ontario (Toronto: University of Toronto Press, 1981); and Anthony Platt, The Child Savers: The Invention of Delinquency (Chicago: University of Chicago Press, 1969).

23 Yearbook, 1932, p. 143.

24 Yearbook, 1937, p. 98. 
black friends. They themselves are intensely interesting children - Ukrainian,

Polish, German, Jewish, Japanese, as well as Canadian and British ${ }^{25}$.

Yet not all efforts to nationalise New Canadian children met with success. At Winnipeg's All People's Mission, Edith Sherwin lamented that "many of our older girls, who have come up through the kindergarten, have left the mission because of the influence of the Greek Catholic Church through the Ukrainian Nationalist Movement. Then, too, it has been hard to battle against the popular opinion of the crowd 26 ." However at the Ukrainian Mission, Kuth Lanigan opined that "many of our oider girls and young people are coming to feel that the mission is a real church home where there is a place for each member of the family to join in worship and in service of our Master ${ }^{27}$." Lanigan was exceptional in that she encouraged the use of the Ukrainian language as a medium for communication, instruction and expression. The Ukrainian Mission had English language classes for the "older people" and "opened a class for children whose parents wished that they be given instruction in the Ukrainian language.... [T] he parents were very grateful, and if the class is continued probably more will come. ...Some of our girls... form[ed] a little choir and learn[ed] to sing some of the old Ukrainian hymns and carols... and they were quite pleased to be able to sing at our [Christmas] concert and quite proud when they were asked to sing at the New Year's Rally ${ }^{28}$."

As Mae Laycock of the Edmonton Ruthenian Home for Girls frankly asserted, the underlying nation-building goals of these activites were reinforced by giving girls "the opportunity... [of] living and working cooperatively with those of other nationalities, under Christian influence. To know and appreciate each other and build up friendships on a basis of Christian living is a great step in the unifying of Canadian life29." By 1936, the Ruthenian Home, renamed the Edmonton Home, had lost its "non-Anglo-Saxon" image, was "open to any girl, Anglo-Saxon or nonAnglo-Saxon, who cannot otherwise have an opportunity for pursuing higher education," (high school or Normal School), and served as an employment agency, locating safe (usually domestic) work for any woman, especially non-Anglo-Saxon women ${ }^{30}$.

25 United Church of Canada, Woman's Missionary Society, Annual Report, 1932-33, pp. 319-320. (Hereafter referred to as UCC, WMS, Annual Report.) Emphasis added.

26 Ibid.,., p. 320.

27 Ibid., p. 324.

28 Ibid., p. 325.

29 Ibid., 1933-34, p. 273.

30 Ibid., 1935-6, p. 300. 
While urban problems pressed heavily upon the financial and human resources of the United Church and served a variety of social, political and religious needs, the "rural" problem posed the greatest dilemma to the United Church. Throughout the late 1920s and the 1930s, the United Church wrestled with the task of formulating an adequate policy and strategy to respond to the "depopulation" of rural regions, especially in Manitoba. The primary reason for the inadequacy of the United Church's response to "rural depopulation" was the inability of church leaders to understand fully the causes and the impact of the depletion of the AngloProtestant population on rural communities. Yet the problem was not new, having been addressed in some detail by the Methodist and Presbyterian churches as early as 191331 .

Within three years of Union, church leaders in Manitoba lamented the gradual depletion of rural Anglo-Protestant population ${ }^{32}$ and the replacement of "Anglo-Saxons" with non-Anglo-Saxon and non-Protestant settlers. According to mission superintendents J.A. Doyle and J.A. Cormie

this condition is likely to continue for many years to come, as the immigration from Europe is more than twice as great as from Britain, and this ratio is not likely to change very materially. As the last census [1921] gave rural Manitoba forty-eight per cent non-Anglo-Saxon in all probability this population is now equally divided between the British and the non-British. Rural fields formerly Anglo-Saxon are disappearing from the lists ${ }^{33}$.

To Cormie and others this "perplexing problem" threatened to undermine the Church and the nation by reducing the core of the Church and the nation: the rural Anglo-Protestant family. In 1934 the Board of Home Missions reflected that "small country churches are both the despair and the hope of Protestantism. They are costly, so far as Home Mission grants are concerned, but are still the source of most of the leaders in every branch of Canadian public life 34 ." For the church, the demographic shift from Anglo-Protestants to non-Anglo-Saxon settlers, who were thought to be antagonistic to Protestant evangelical efforts, meant the undermining of

31 See Methodist Church and Presbyterian Church Rural Suvrvey-Swan River Valley. Manitoba - of the Agricultural, Educational, Social and Religious Life (Toronto, 1914); John MacDougall, Rural Life in Canada: Its Trends and Tasks [1913] (Toronto: University of Toronto, 1973); David Jones, "We'll all be buried dow'n here": The prairie dryland disaster 1917-1926 (Calgary: Historical Society of Alberta, 1986); David C. Jones and Ian MacPherson (editors), Building Beyond the Homestead: Rural History on the Prairies (Calgary: University of Calgary Press, 1985).

32 "In two constituencies in Western Manitoba ninety-four townships lost population while seventy gained. As a result every town and village, with the exception of one and Brandon, lost in population. In addition to this the character of the population has changed. Tenant farmers are increasing in numbers. ..."Yearbook, 1928, p. 310.

33 Ibid, p. 311.

34 Yearbook, 1934, p. 134. 
self-sustaining charges and community life, an increase in the number of augmented or mission stations, the loss of ordained ministers from rural areas, and the increased use of student missionaries to provide for religious services for the remaining "Anglo-Saxon" settlers and the burgeoning New Canadian population.

As late as 1939, Cormie, commenting upon the 1935 quinquennial census, argued that

There is no reason to believe that the trend was stopped in 1936. If it continued there are 9,000 fewer people of British origin in Manitoba than at the beginning of the decade, and 27,000 more non-British.... The Europeans have brought their old-world religious preferences as well as their social customs. In the town of Morris, with a population of 800 , there are six churches, a United Church of Canada church, a Roman Catholic and four German language churches.

The decline in numbers of British stock means dwindling of United Church folk, generally so situated that rearrangement of the territory is difficult and often impossible 35 .

"The replacement of the old Canadian stock by the New Canadians," Cormie contended in 1940, "continues to weaken many rural United Churches". Cormie and others feared the growth and concentration in settlement patterns of New Canadians ${ }^{36}$.

The United Church respond to this crisis for the rural church on the prairies by amalgamating charges and increasing the size of the territory served by ministers. This stratgy, one that reflected a movement initiated prior to Union when the Presbyterian and Methodist churches agreed not to have overlapping charges, was to amalgamate smaller charges into one moderately-sized charge (similar to the process whereby provincial governments consolidated school districts) ${ }^{37}$. One benefit of the amalgamated charge was thought to be a stronger congregation. In 1927, for example, the Board of Home Missions reported that "as a result of Church Union a large number of churches situated in the same district have united their forces and... these local unions have resulted for the most part in the formation of stronger self-supporting congregations ${ }^{38}$." Self-supporting congregations, as the description suggests, should have enabled the church to allocate monies that would have gone to augmenting the operation of separate congregations to other more needy areas or more needy projects, including the erection of manses in remote charges ${ }^{39}$. In rural Manitoba,

35 Yearbook, 1939, p. 91.

36 Yearbook, 1940, p. 143.

37 See Paul Voisey, Vulcan: The Making of a Prairie Community (Toronto: University of Toronto Press, 1988), pp. 180-186.

38 Yearbook, 1927, p. 109.

39 For a discussion of "self-supporting" charges and the apparent under-representation of augmented charges in church records, see Voisey, Vulcan, pp. 188-189. 
J.A. Cormie included among the benefits of Union the positive impact of amalgamation the closing of "many superfluous Churches, for here, as in rural districts elsewhere, there were too many Churches." Yet while amalgamation temporarily solved the problem surplus rural churches, other rural churches still "suffered from the loss of their families." The mere "rearrangement of preaching stations" was deemed insufficient ${ }^{40}$. Yet, by rearrangement other charges had become self-sustaining.

In the minds of many congregants and ministers, amalgamation of charges, first as a result of Union and "rural depopulation" and then, in the 1930s, as a result of agricultural failures and further dislocation of the rural population, was an incorrect strategy. Although, from a national perspective, amalgamation of increasingly smaller rural congregations made fiscal sense, from the perspective of the local congregants, amalgamation (and the resultant closing of more local churches) did not make spiritual, moral, or social sense. This was especially the case in the era of the depression when ministers feared the impact of continuous agricultural failure and economic uncertainty on the spiritual, social and psychological health of their communities. As early as 1931, the Alberta Conference of the United Church "deprecate[d] the withdrawal" from frontier appointments, "necessitated through the persistent policy of amalgamation. We believe that the constant effort to curtail expenditure, and the program of retrenchment in recent years, is weakening the home base of our missionary activities ${ }^{4}$." Yet in spite of this and other protests, the policy of retrenchment continued.

Another response to the problems encountered on the rural charges was the establishment of a Commission on Rural Work to study these problems. The Commission, established in 1930, reinforced the view that the rural problem had "been partially obscured by the changes preceding, following and incident to Church Union," especially the amalgamation of charges and congregations. While consolidation would continue, it was "not immediately apparent [to the Commission] what type of consolidation [would] provide service adequate to the needs of the community suffering from declining or shifting population ${ }^{42}$." Although the Depression in its fullest fury intervened before the Church developed a comprehensive approach to the issue, the Manitoba Conference continued to

40 Yearbook, 1929, p. 137. An example of the problems that confronted the Church was the charge of Oakburn, Manitoba. In 1920 the Oakburn district held two "self-sustaining pastoral charges." By 1926 "these were amalgamated into one, which latterly... receiv[ed] a grant." In 1929, "a minister was not appointed and... the different congregations of the charge [were] distributed between two neighboring charges, one of which was about to become an aid-received charge." Yearbook, 1930, pp. 185-186.

41 AC, Conference Minutes, 1931, pp. 32-33.

42 Ibid., pp. 204-206. 
regroup charges to reduce the number of missionaries required and thus save on grants to aid-receiving charges ${ }^{43}$.

Yet as rural regions were being depopulated of Anglo-Celtic stock, frontier mining communities and transportation centres such as Flin Flon, Cold Lake and Churchill in Manitoba, Hudson Bay Junction and Meadow Lake in Saskatchewan, and the Lloydminister and Cold Lake regions of Alberta as well as the ubiquitous urban and suburban districts grew rapidly. The United Church, the Presbyterian Church and Anglican Church looked upon the expansion of mining in the north with some apprehension. Earlier experiences with frontier resource extraction centres steeled the churches for the inevitable demand for more religious services at the same time as prostitution, intemperance and sabbath desecration proliferated.

The United Church reacted swiftly to the ever-present threat of a "progressively paganized" frontier ${ }^{44}$ by sending ordained missionaries and summer students into these new settlements and providing small sums for the construction of churches at sites such as Churchill, Cold Lake and Flin Flon. Few observers recognized the immensity of the northern frontier. In 1928, J.A. Doyle described the scope of the "hinterland" in Manitoba. "This 'Prairie Province'," he noted, "is after all only twenty per cent agricultural, and contains a large area covered with spruce forest and one of the largest mineral fields in Canada." Doyle described the sparseness of settlement and the need for the church to develop a clear policy on how best to serve a growing yet dispersed population ${ }^{45}$. One concession to these frontier regions was the appointment of ordained missionaries, often with surprising success, at least initially.

If this resettlement to the northern resource towns had been orderly, or at least accomplished within the usually disorderly fashion, the church might have been able to meet most of the spiritual needs 46 . The problem was, however, that the relocation of population to the northern frontier accompanied and was a response to economic depression and agricultural disasters in southern districts. While mission superintendents in southern Manitoba and southern Saskatchewan recorded the outflow of AngloCeltic settlers, northern superintendents staggered under the tremendous inflow of new residents. In his 1932 report, Rev. J.L. Nichol, superintendent of missions in Northern Saskatchewan, reported that "into the whole north of our province it is estimated that 20,000 new settlers have

43 Yearbook, 1931, p. 139.

44 Yearbook, 1930, p. 159.

45 Yearbook, 1928, pp. 311-12.

46 See Yearbook, 1926, pp. 321, 323: Ibid.. 1928, pp. 312-315, 317-318; Ibid., 1929, pp. 132-136. 
gone during the past two years ${ }^{47}$." Rev. M. H. Wilson of Northern Alberta presented a detailed report on conditions in his mission district:

The northern Presbyteries, Grand Prairie and Peace River, and the more easterly Presbytery of St. Paul have received quite an influx of settlers during the year. These came chiefly from the drought areas of Alberta, Saskatchewan and Manitoba. Very many of them trekked these weary miles from their former home to what was, to them, a land of promise. Many of those who came from Saskatchewan and Manitoba wended their way through Alberta into the Peace River Block in British Columbia. There were caravans of these migrants to be seen on the roads any day in August, and the beginning of September pressing on through Grand Prairie and adjacent towns to their terminus. The old-fashioned prairie schooner was in evidence. Loads of household utensils and farm implements, with perhaps a few head of stock travelling alongside, and Ford cars loaded to capacity, intermingled in the procession... ${ }^{48}$.

The impact of this sudden internal migration on the rural communities in the south and on the new settlements in the north cannot as yet be determined. For the northern presbyteries, the impact permitted some to expand, to attract more ordained and student ministers, to build more churches, and to serve a greater clientele. More research is essential if the impact of economic depression, rural depopulation, and frontier development on the social and spiritual life of the communities is to be assessed.

The United Church could not meet the "challenge of national crisis" in which it found itself.

\section{Mission Work and the New Canadian}

In the late 1920s and 1930s, United Church mission workers represented well the ethnocentric views of the Canada's middle class toward the New Canadian. The concentration of immigrants of non-Anglo-Celtic heritage in the central cores of the cities undermined, in the view of these mission workers, opportunities for the smooth assimilation of the children and the immigrants themselves into Canadian society. Concentrated settlement encouraged the maintenance of ethnicity, the proliferation of ethnic support agencies, and radical elements of the communities 50 . In addition, since many new immigrants were concentrated in housing considered substandard by social reformers within and without the church, issues of public health, over-crowding, sanitation, education and social welfare also garnered the attention of the mission workers.

47 Yearbook, 1932, p. 152.

48 Yearbook, 1932, p. 167

49 Yearbook, 194, pp. .

50 A.E. Archer, The Ukrainian People in Canada and Our Work Among Them (n.p.: Alberta United Church Conference, 1931). 
Most rural church workers also viewed non-Anglo-Saxon immigrants and second-generation New Canadians as threats to their vision of Canada as "His Dominion" 51 . In the period 1925 to 1940 , mission workers lamented that New Canadians had yet to integrate into the Canadian social life. Moreover, the replacement of rural Anglo-Protestant populations by nonAnglo-Saxon settlers undermined the existing social structure of rural communities and made the church's task of serving an ever-more dispersed cleintele more difficult. Rather than perceiving this demographic shift as an opportunity, United Church mission superintendents saw it as a threat (anti-ethnic nativism). In the depresssion years, they also feared that communism would once again become a major force in many ethnic rural settlements (anti-radical nativism). Finally, United Church missionaries feared the growth of sects within the ethnic communities in rural Manitoba and Saskatchewan. Irreligion and radical sectarianism, it was thought, would combine with other less savoury aspects of the immigrants background to produce an un-Canadian, un-British, and un-Christian people.

The predominant theme within the writings of mission superintendents was the threat that New Canadians poses to the Canadian polity and to the Protestant ethos of the nation. But while the most prominent ideological underpinnings of the United Church mission enterprise in western Canada in the inter-war years were strongly anti-alien and antiradical, these co-existed with a commitment to integrate the New Canadians into Canadian social life and to win them to the United Church. While the majority of mission superintendents and spokesmen for the church viewed the New Canadian in a negative light, other workers were genuinely respectful of the New Canadian and acknowledged the contribution that New Canadians might make to the United Church. These workers perceived the New Canadians as agents who could extend the twin gospels of Christianization (evangelical Protestantism) and Canadianism throughout the ethnic communities. Moreover some saw New Canadians as the agents through which the reach of Protestantism could be extended back into Eastern and Central European states of Poland and the Ukraine. However, United Church ministers and missionaries collectively failed to respond to the New Canadians and their needs (as defined by the United Church agents) in a fashion that was consistent within or across conferences. Most United Church ministers indiscriminantly viewed New Canadians as foreigners ethnically, culturally and religiously. These agents of the United Church were nativist and some were racist.

51 See Clifford, “'His Dominion': A Vision in Crisis"; Grant, "The Reaction of WASP Churches..."; and Owen, "Building the Kingdom of God". 
These conflicting yet coexisting themes appear with regularity within the reports of the Home Mission Board and the Woman's Missionary Society. For example, the WMS collectively believed in the necessity of the New Canadians conforming with Canadian norms and mores (Angloconformity) and worked to achieve these goals through a variety of institutions, including hospitals, health units, boarding schools, and school homes. These missions, asserted the 1935 report of the WMS, aimed

to give real help to people in need; to bridge barriers of class and race by sincere friendship; to help non-Anglo-Saxon Canadians retain their love for their own cultural background and yet to make their contribution with us to Canadian life; to interpret the Christian way of life to those who do not know Him; to develop Christian character; and to lead boys and girls and men and women into the fellowship of the Christian Church 52 .

Few mission superintendents subscribed to this view of cultural pluralism ${ }^{53}$. More often they were patronizing nativists who had as their short and long term goals the eradication of the religious and cultural mores of the New Canadians. M.H. Wilson, home mission superintendent in Northern Alberta, did not assuage New Canadians' suspicions about the aims of United Church when, in his review of work among the "great multitude of peoples of foreign birth", he queried if the United Church and Canada could "afford to permit them to remain foreign to the Christian ideals of citizenship which we claim? Surely not!" 54 Central Europeans, reflected W.R. Donagh of the rural Vita Social Institute, had "their own interpretations of Christianity" that were "full of superstition." Donagh believed that older immigrants resisted assimilation to Canadian ideals out of a sense of loyalty to their homeland 55 . Yet attachment to traditions of the homeland appeared to be selective. Ukrainian immigrants, stated one missionary, "had lost all practical interest in the churches in the Old Land" but retained "an inarticulate attachment which expressed itself in at least a negative way." Ukrainians who joined with a Protestant church were charged with "disloyalty". To be unchurched, a major error in the views of these United Church spokesmen, was, to the Ukrainian settlers, "not nearly so great a crime as to become associated with a church which had its

52 Yearbook, 1935, pp. 173-174.

53 In my view, there is a major difference between, on the one hand, offering services to a potential client group, stating explicitly one's long term goals of evangelism and assimilation/amalgamation and accepting a certain degree of cultural variation, and on the other hand, offering the same services with a similar long term goal and at the same time denigrating the cultural traditions or other characteristics, including religious predispositions, of the client group. Unfortunately, again in my view, United Church missionaries fell within the second category, that of cultural nativists who were tainted with racism.

54 Yearbook, 1929, p. 144.

55 Yearbook, 1926, p. 323 
birth in another land. National patriotism included a certain form of worship56." Not recognizing the irony in this and other similar statements, United Church ministers and missionaries expressed sentiments that, even in the context of the period, were ethnocentric.

While most missionaries adhered to the old-style anti-foreign nativism, others expressed their hopes for the missions and the people that they served. These hopes were based on three movements within the New Canadian populations. First, United Church missionaries placed great faith in the spiritual impact of the "great Protestant movement in Central Europe." To the Board of Home Missions this movement had a positive impact on the receptivity of older "New Canadians" to the teachings spiritual and political - of the church. More recent Central European immigrants who claimed membership in a Protestant Church brought with them "a new idea of patriotism. It [was] no longer disloyal to be Protestant." Indeed, the Board chastised Ukrainian-Canadians for their reluctance to accept as legitimate the Protestantism of the Canadian churches. "[I]f the Canadian Ukrainians are to be interested in and associated with their brethren in the homeland who are in the midst of one of the greatest religious movements of history, they must share with them the new truth ${ }^{57}$." The experience of the missionaries seemed to justify an enthusiasm for this new "reformation" in Central Europe and its perceived impact on "New Canadians". "Never has the Ukrainian in Canada or in his Home Land been so eager to have the gospel preached in simplicity and directness. This openness of mind on the part of the Canadian Ukrainian is partly due to the reflex action of religious movement that is now taking place among many Central European countries... the greatest liberalizing religious movement of history...58"

Second, the Home Mission Board and the Woman's Missionary Society expressed great faith in evangelical and nationalising work of the hospitals, social service institutes and school homes. To Thomas Powell, home mission superintendent in Northern Alberta, the influence of mission staff was best judged "in changed conditions in the homes of the people" 59 . School homes and boarding and hospitals all served to uplift New Canadian clients spiritually, politically, socially, and intellectually. Third, a new leadership within the ethnic communities was developed within these mission institutions, especially the schools. To United Church missionaries, evangelism and assimilation would occur more efficiently only when

56 Yearbook, 1926, p. 350.

57 Yearbook, 1926, p. 334.

58 Yearbook, 1927, p. 113.

59 Yearbook, 1926, p. 326. 
a Protestant New Canadians leadership was developed within these communities ${ }^{60}$. To the Woman's Missionary Society.

\begin{abstract}
No more effective way has been discovered for providing Christian leadership for non-Anglo-Saxon colonies than the School Home or boarding School. We recognize that China can only be won by the Chinese, Africa by the Africans; can we not equally realize that the great majority of the strangers within our gates can only be reached by those of their own nationality. The boys and girls of the Ukrainian, Ruthenian, Lithuanian, Russian, French, Austrian, and Italian peoples living within our School Homes or Boarding Schools, as the case may be, are the citizens of tomorrow who should be the leaders for these people within Canada.... [Moreover] the free-mingling of young people from all racial groups affords the greatest possible Canadianizing influence. The divisions of the Old World will be forgotten in the camaraderie of the New, ... leaving behind all distinctions of race $^{61}$.
\end{abstract}

Moreover the Board of Home Missions pinned much hope for the eventual assimilation of the New Canadian as Christian Canadians on the work of the minister/missionary in the field, not the least among whom were the ethnic missionaries. As early as 1903, the Presbyterian Church had employed ethnic missionaries to preach the gospel to the Ukrainian people in western Canada. By the late 1920s and throughout the 1930s the United Church had ethnic missionaries of Ukrainian, German, French, Hungarian, Chinese and Scandinavian descent working among their own people in western Canada. While some worked independently, others worked under the oversight of an Anglo-Protestant supervisor.

The success of United Church missions to the Ukrainian, Hungarian and German communities depended in great measure on the ability of missionaries to be able to speak with their clients. Because of the inroads of "Communist agitators" among the Ukrainian communities in western Canada, and for more practical reasons, it was "essential that the missionaries among these people should understand the language..." 62 . Facility with the language was of utmost necessity when dealing with the older settlers and the most recent immigrants whose command of the English language would have been extremely limited. In the view of the WMS, it was fortunate that some missionaries were "themselves non-AngloSaxons" while others had learned "to speak at least one of the European

60 See Michael Owen, "Keeping Canada God's Country"; Vivian Olender, "The Reaction of the Canadian Presbyterian Church towards Ukrainian Immigrants (1900-1925): Rural Home Missions as Agencies of Assimilation" (unpublished Ph.D. dissertation, University of Toronto, 1894): Michael Zuk, "The Ukrainian Protestant Missions in Canada" (unpublished paper in author's possession); Vivian Olender, “' 'Save Them for the Nation ': Methodist Rural Home Missions as Agencies of Assimilation, "Journal of Ukrainian Studies 8:2 (winter 1983), pp. 38-51; Vivian Olender, "The Canadian Methodist Church and The Gospel of Assimilation, 1900-1925", Journal of Ukrainian Studies 7:2 (Fall, 1982), pp. 61-74.

61 WMS, AR, 1926, p. 350; Yearbook, 1927, p. 114.

62 Yearbook, 1928, p. 309. 
languages". The usefulness of these missionaries multiplied as they were able to "reach the mothers who are inclined to stay at home and thus remain strangers to the customs, traditions and ideals of Canada. The missionary who can talk with them in their own tongue becomes a real friend, and a more effective interpreter of Canadian life and of the Gospel of Jesus Christ 63 ". J.A. Cormie agreed that "as long as there are newcomers from continental Europe and older immigrants who have not become familiar with the English language, the foreign language churches will be necessary...[but] effective service to the|se] people of Canada... can oniy be done by a Canadian Church and obviously a large share will fall to the United Church64". The Commission on Non-Anglo-Saxon Work, which did not have a single New Canadian among its members ${ }^{65}$, hesitantly took a broad view of the church's work among New Canadians. Reluctantly it endorsed the view that church services should be bilingual as long as there were "considerable numbers of people in this country who are not familiar with the English language66". The goal, of course, was the eventual elimination of foreign language services and the assimilation of non-AngloSaxons to the dominant Anglo-Protestant mores and English language.

While ethnic missionaries had an advantage over Anglo missionaries, for they knew the language and the culture of the clients, the United Church had difficulty attracting suitable candidates to minister among the various ethnic communities. The main stumbling block, it would seem, was the attitude of the Church bureaucracy to missionaries of non-AngloSaxon heritage. The Commission on Non-Anglo-Saxon Work urged that "the greatest care should be taken to secure and train for our Non-AngloSaxon work an adequate number of missionaries from both Anglo-Saxons and Non-Anglo-Saxons in Canada 67 ". In the years following Union, prairie conferences experimented by sending out into the field teams of summer students: one Anglo-Saxon and the other Ukrainian. The Manitoba Conference sent out seven pairs to Ukrainian mission fields in 1928 but,

63 Yearbook, 1935, p. 173.

64 Yearbook, 1930, p. 185. Emphasis added.

65 While the Commission did not have New Canadians as members, it did take "testimony" from current and past New Canadian missionaries, including Rev. E. Eustace of Winnipeg; Rev. John Gregorash of Canora, Sask.; Rev. M.P. Berezynski of Insinger, Sask.; Rev. R.M. Ponich of Edmonton; Rev. T. Hannachko of Three Hills, Alberta, and Rev. E. Perich of Andrew, Alberta. See "Meetings of Representatives of the Western Section of the Commission on Non-Anglo-Saxon Work with Western Ukrainian Ministers of the United Church of Canada," United Church of Canada Archives, United Church of Canada, Board of Home Missions, Series II, Section I, Box 11, File 428; "Memorandum by Dr. Dorey re: Questionnaire on New Canadian Work", UCCA, UCC, BHM, Series II, Section I, Box 11, File 422.

66 Yearbook, 1939, pp. 206-209

67 Ibid., p. 208. 
over the next decade this experiment was eliminated for two reasons: budget and the lack of conclusive results. As early as 1929, J.A. Cormie conceded that "there is some difference of opinion" on the effectiveness of these teams. Yet both Manitoba and Southern Saskatchewan continued to send out teams of students, although on a reduced scale. In the opinion of J.A. Doyle, superintendent of missions in Southern Saskatchewan, the students' work "justified the expenditure involved". The student missionary sent out to the Old Stuartburn field in Southern Saskatchewan, for example, had been trained in one of the church's city missions and was "an acceptable preacher68". Other reports confirmed that Ukrainian students obtained good results and this supported the initiatives of the United Church to find ministry candidates from among the ethnic communities to meet the perceived need for bilingual ministers. However, there was considerable disagreement about the efficacy of this emphasis on ethnic missionaries. M.H. Wilson of Northern Alberta attributed the lack of assimilation of the New Canadian to the use of ethnic missionaries. "More and more", he stated, "the feeling seems to be developing that the work among the Ukrainian people could be more efficiently done by Anglo-Saxon men. Our own men seem to be able to command the respect of these people to a greater extent than men of their own race... Time may perhaps help to solve this part of the problem. The great fact is that they are here and cannot be neglected"69. Moreover, ethnic missionaries were placed in a subsidiary role to their Anglo colleagues.

The disagreement over the value of teams of Anglo-Saxon and nonAnglo-Saxon students corresponded to the re-evaluation of the whole United Church mission enterprise in the early 1930s. By the early 1930s some home mission superintendents questioned the will of the United Church to carry on a viable home mission enterprise. M.H. Wilson of Northern Alberta pointed out that the United Church (and Canada) had received good value for its money and effort:

Out force of workers is limited and our methods of work may not be the best, but we are doing something... [Converts] are comparatively few, and if success in this venture is to be gauged by numbers the odds would seem to be against us.... We may ask, therefore, if in a decade or two decades there is any visible changes come over homes? Are the habits of the people what they were ten years ago? Is there any evidence of a changing life? Is the moral atmosphere in any way elevated? We are sure that an affirmative could be given to all these questions.

68 Yearbook, 1929, pp. 137, 139: Doyle argued that "this evolution can and will be repeated in many places in the West if we are wise enough to embrace all opportunities, both in securing and training students and in entering these settlements as they develop in a knowledge of the English language, and come to appreciate the higher cultural agencies of our Canadian life". Yearbook, 1930, p. 185.

69 Yearbook 1932, p. 168. 
The leaven is surely penetrating the meal and time will see the whole mass leavened and these people splendid" 70 .

It was the persistence of dedicated home missionaries, especially the ethnic missionaries, that kept the United Church mission among the nonAnglo-Celtic settlers alive. Ordained and lay missionaries, such as Dr. Franc Hoffmann, missionary to the Hungarian population in Northern Saskatchewan, Rev. John Gregorash, Ukrainian missionary, and Martin Halinen, a student missionary serving the community at Dunblane, Saskatchewan, to name but a few, served the church's interests among the ethnic minorities of western Canada. For example, two Ukrainian ministers in the St. Paul Presbytery, Alberta, and the presence of three school homes and a hospital at Smoky Lake, apparently overcame "opposition" to and "suspicion of their real purpose". "Although their success ha[d] not been marked as yet," they had broken down "prejudice and antagonism on the part of the people who had practially separated themselves from all Church connections"71. In Northern Saskatchewan, Hoffmann, "our missionaryextraordinary" was indefatigable. Halinen "received about a dozen Finnish young people into full communion after having held preparatory classes for some weeks" in 1932. In his assessment of the work of these individuals, Nicol saw the work of these missionaries as assisting the church and, importantly, preserving from the inroads of communism the ethnic communities in his conference. Yet, he lamented, "when will we be able to serve more of these our loyal citizens? Who can estimate the strength they can give our Church in the future? While many of our older Canadians are indifferent, these few, at least, show a courage and a conviction that is worthy of the best traditions of the Covenanters of an earlier day"72.

Accurate assessments of the work of these ethnic missionaries are sparse. One can find examples of the positive work of the missionaries and, as important, the activities of the graduates of the missions. On more than one occasion, the work of WMS school homes graduates, who have carried "with them the Christian teaching and influence received from our workers and are now making their own worth-while contribution in many communities"73 garnered comment in the Yearbook and the WMS Annual reports. But critical assessments of the work were rare and those that did appear were designed to ensure the continued support of the Board of

70 Yearbook, 1929, pp. 143, 144.

71 Yearbook, 1928, pp. 303-304.

72 Yearbook, 1932, p. 153; See also Saskatchewan, Royal Commission on Immigration and Settlement, "Hearings of the Commission", volume 2, 1932, pp. 109-130.

73 Yearbook, 1933, p. 174. 
Home Missions, however contracted, and the Woman's Missionary Society.

The real concern was not that the missionaries were not succeeding in their difficult undertaking but that the United Church, as a national church, was failing to meet the demands of the field. In 1930, the Board of Home Missions noted a severe decline in the numbers of missionaries to the Ukrainian population: "Over forty missionaries were employed at one time, "the report stated, but "at present, the staff consists of ten ministers and three students. Though the membership of the Ukrainian people in the United Church after all these years is disappointing, yet a great liberalizing movement can be traced directly to these early efforts." As a result of neglect and lack of properly trained leaderhsip among the Ukrainian missionaries, much ground apparently had been lost ${ }^{74}$.

Major criticisms of Church policies arose in the 1930s. Superintendents, although aware of the financial problems the Board was encountering, did not withhold their disappointment over the inability of the Board to recognize and pursue its opportunity among New Canadians. J.L. Nicol, of Northern Saskatchewan, lamented "the extent of the work carried on by our church among the non-Anglo-Saxons in the northern half of the province." Although the British stock was outnumbered two to one and the inroads of communist agitators appeared to be growing, the United Church had "as agencies... to these non-Anglo-Saxon people two ordained men, three students [one Scandinavian, one Hungarian and one Ukrainian], one hospital, one bi-monthly paper [Hungarian], and one school home at an approximate cost to our Board of less than $\$ 13,000 \ldots$. To Nicol, the United Church should not "rest snugly, feeling that we have done our part in developing Christian lives and National Character." In his opinion, mission work for New Canadians did not receive its share of the funds 75 . To Nicol, the United Church had not and was not "playing a very important part in shaping" the future social and national ideals and character of New Canadians.

The anti-radical nativism of mission workers, as among many ministers and adherents of the United Church, came to the fore in these reports. Ethnic communities were perceived as the hotbeds of communist agitation. As early as 1928, the report of the Board of Home Missions asserted that Ukrainian communities were major stumbling blocks to the development of a common Canadian identity in Western Canada. Part of the problem, in the view of the Board, was the fact that the Ukrainians

74 Yearbook, 1930, p. 164.

75 Yearbook, 1931, pp. 136-137; 1934, pp. 156-157. 
formed the third largest community in Canada, a group whose "natural increase is very rapid" and added to annually through the "large numbers of new arrivals." Being "very strongly national in sentiment" Ukrainians resisted the assimilationist thursts of the host society, including those of the Church76. Communism and a "narrow nationalism," claimed D.C. McGregor and R.B. Cochrane, permeated the "immature thinking" of new immigrants and the second and third generations in Canada 77 . The missions were to be bulwarks against this insidious "foreign" strain and relied on the clients to build up a "fine spirituai infiluence in... conmuniities where a communistic element has developed"78.

At the same time as the Board recognized the importance of the home missions for their spiritual, material 79 and social needs, the Church was unable to respond adequately. J.L. Nicol acknowledged in 1933 that while "there are great possibilities for good or evil, when the quality of our citizenry... is to be considered,... we have to confess that we as a United Church, are not doing very much in determining them..." 80 . Other mission superintendents acknowledged that the United Church, in essence, had failed to meet not only the demands placed upon it by others, including the New Canadians, but, as importantly, by its own people. While the missionaries "among the Non-Anglo-Saxons [were] sledding away" in 1934,81 by 1937 the Board of Home Missions reported that "the work

76 Yearbook, 1928, p. 309.

77 Yearbook, 1936, p. 105. Emphasis added

78 Yearbook, 1937, p. 131; 1930, p. 162. United Church missionaries, ministers and volunteers failed to recognize as legitimate the "nationalism" among New Canadians and a sense of sympathy among these people with the trials of compatriots in their homeland. United Church leaders, as a group, spoke of Great Britain and Scotland as the "Motherland" or the "Old Land". At times, United Church ministers appeared to be more directed toward Scotland or England than to Canada and were as guilty of maintaining an attachment to the homeland as were more recent immigrants.

79 Yearbook, 1932, p. 134: "Probably due in some measures to the fact that a great proportion of them are out of work, the non-Anglo-Saxons have been turning to our institutions in the great cities in ever increasing numbers. Friendless, penniless, and in continual fear of deportation if they should have to appeal to city authorities for relief, hundreds of these people have been crowding our 'Churches of All Nations' making use of the facilities provided. Scores of them have been in catechumen classes and have been received into the Church, and it is greatly to be regretted that at this moment when they are most susceptible we are not in a position to increase both our staff and our facilities for working amongst them. ...The situation in regard to the work among NAS in rural communities is not nearly so satisfactory, due to a decrease in the number of workers. The seriousness of neglecting this portion of our population is seen at once if one turns to the statistics issued by the Dominion Government which show that in 1920-31 21, 392 persons became naturalized Canadian citizens. The largest single group were Russian - 4,069, and the second group, Poles - 2,522".

80 Yearbook, 1933, pp. .

81 Yearbook, 1934, p. 173. 
among the New Canadians [had] lapsed sadly" 82 . These assessments of the dwindling strength of the work were made as the demand grew (partly due to the depression) and the Home Mission Board clarified its goals through the Commission on Non-Anglo-Saxon Work and a statement of faith: The missionary enterprise, declared the Board in its 1934 statement, "is an endeavour of idealists to produce through the religion of Jesus Christ a Canadian Christian citizenship out of the many varied and mutually contributing cultures." Missions to the New Canadians would "help the various racial groups in Canada to develop and live a normal life..." 83 .

Throughout the 1930s United Church missionaries and ministers served the spiritual, social and material needs of the New Canadian, whether in the city, in rural block settlements or on the frontier, effectively and in a manner that, in many cases, did not win converts but did build up friendships. Hence, in spite of the efforts of the Church to trim its budgets, through the commitment of the field staff, it was able to maintain its work among New Canadians ${ }^{84}$. However, this work changed in subtle and notso-subtle ways. Gradually the United Church moved away from a strident nationalism to a position that, while adhering to the principle of assimilation of the New Canadian to the mores of Anglo-Protestant Canada, began to express a belief in a multi-cultural or pluralist view of Canada as a nation.

\section{Concluding Comments}

The major conclusion that one draws from this paper deals not with the intricacies and trials of the home mission enterprise in the inter-war period but with the great need to conduct more research on issues related to church activities in this period. Some of the fruitful areas for further research have not been outlined. Among those upon which I have commented are the role of student missionaries, lay missionaries and women missionaries (women as ordained or lay missionaries as opposed to women as medical, educational or social service missionaries); the rural ministers'abandonment of charges for a combatant's role or chaplaincy during World War II; the role of the church as a barometer of social change (e.g., rural-urban demographic shifts and changing attitudes toward social and material relief during economic depressions); and the

82 Yearbook, 1937, p. 87.

83 "Second - To relieve the Foreign Missionary enterprise of embarassment. In a shrinking world it becomes increasingly evident that when races or classes in Canada cry out from racial antagonisms or discriminations the foreign missionary hosts retreat. ...[and] Third - To purify and strengthen the national will." Yearbook, 1934, pp. 13-135.

${ }^{84}$ For reports on the continuing work among the New Canadian populations see Yearbook, 1937, p. 99; 1938, p. 121; 1940, pp. 145-146. 
shifting ideological perspectives within the church and among the clergy and laity. These issues demand indepth analyses. The ordination of women, the shifting role of ethnic missionaries within the church (and the gradual replacement of the west by Southern Ontario as the centre of New Canadian missions), the economic depression and agricultural failures forced the United Church to come to grips with social, economic and theological concerns. What is intriguing, however, was the apparent lack of debate within the Home Mission Board over theological and social issues. The reports of the Board of Sociai Service and Evangelism were much more radical but the home missionaries were the front line personnel who dealt with relief, with the stress of economic depression and agricultural failures on the congregants. It was the home missionaries who attempted to determine if thirty years of missions to the New Canadian had failed, and why. It was upon the home missionary that the amalgamated charge placed ever-increasing burdens. It is not surprising, therefore, given the pressing nature of day-to-day affairs, that there was little theological or social debate. Yet one would expect that these men, for most were men, would have been more reflective in their reports.

The day-to-day concerns confronted by these ministers and missionaries were immense. Although they recognized as well the impact of economic restraints on the budgets of the national church, indeed their own budgets were severely constrained as a result of the agricultural failures of the 1930s, they lamented the inability of the national church to expand its services to the western provinces. More research is needed on the relationship between the national church and the regional conferences, the expansion or the amalgamation of fields, the location of ministers, and the development of national priorities.

Since this paper has relied upon the published annual reports of the Board of Home Missions, the Woman's Missionary Society, and the Alberta Conference of the United Church, there is need for much indepth research into the correspondence of the personnel in the field, the personal papers of these individuals, and, as importantly, the communicants and other clients of the Church. Without more detailed study of this nature, the picture of home missions in western Canada will remain subject to broad interpretations and will not be integrated within the broader social history of the church and the region.

In addition, there remains much room for research on the role that women played as administrators of missions (nationally and on the local level) and as financiers of local churches. The attention that has been given to the ordination of women and their participation in the courts of the church often masks the very important, indeed critical, roles that they 
played within the local congregations. Women's societies often determined whether a church remained as a viable congregation (financially and socially). Little is known of this role. Also, while I have considered the United Church's missions to New Canadians from the view of the church, there is a need to consolidate the information that exists within the published reports of the home mission board, the letters and papers of the "ethnic" missionaries, and the many local histories of ethnic churches. Ethnic missions need to be analysed from within, with the dynamics of local congregations being explored, and from without, with the relations between the ethnic churches/missionaries and the mission superintendents and the mission boards. One cannot assess the success or failure of individual missions, for the mission enterprise itself was "successful", unless one can examine these inner dynamics.

Finally, we need to assess the theoretical boundaries for this research. Is the typology borrowed from Palmer and Higham an adequate paradigm in which to consider missions to ethnic communities? How will feminist paradigms impact upon the discussions of mission work, especially the subsidiary role in which the WMS was cast and understood? We need to reassess the role that the local congregation or the communicant had in the corporate and social history of the church (too often we still write church history from the top down), and what it is we mean when we speak of missions. Only in these ways will we be able to assess, in the words of the Commission on Non-Anglo-Saxon Work, how well the United Church, "as the latest expression of Canadian Christianity" adequately provided for the spiritual and moral needs of the Canadian people. 85

85 Yearbook, 1930, p. 206. 